\title{
Downregulation of NGAL is Required for the Inhibition of Proliferation and th Promotion of Apoptosis of Human Gas Cancer MGC-803 Cells
}

\author{
Ming-Yang Han ${ }^{a} \quad$ Jie-Wei Nie ${ }^{a} \quad$ Yuan-Yuan Lib Yuan-Zeng Zh. Gang Wu \\ aDepartment of Gastrointestinal Surgery, Henan Provincial Peopr o. Thengz, $\mu_{1}$, 'Reproductive \\ Center, Henan Provincial People' Hospital, Zhengzhou, China
}

\section{Key Words}

Neutrophil gelatinase-associated lipocalin • G siler $g$ • Gastric cancer • Proliferation • Apoptosis

\section{Abstract \\ Background/Aims: Gastric prognosis as well as unsatic} (NGAL) has been reported arie
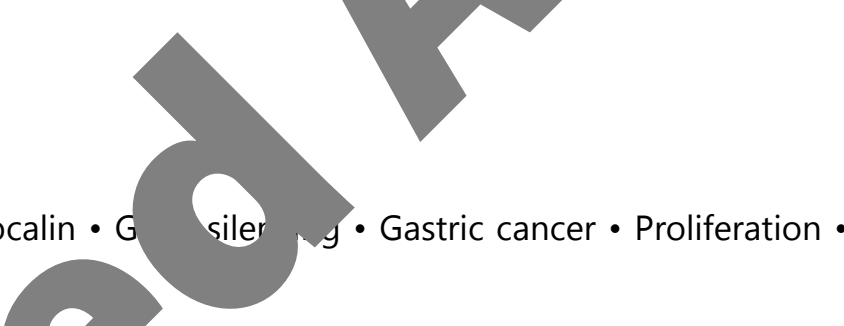
This study aims to explo apoptosis of human gas with gastric cancer MGCne effec treament. Neutrophil gelatinase-associated lipocalin and recombinar protein and ar $\mathrm{str}$ polymeras hair $a c$ le aspects of human tumor, including gastric cancer canc" MGC- 803 cells. Methods: This study included 87 patients vere collected and mainly treated with siRNA against NGAL apopto re te y flow cytometry, and cell proliferation was detected by water soluble t trazoli (WST-1) assay. The effect of NGAL gene silencing on tumorigenicity of MGC-803 1 vivo detected through establishment of xenograft in nude mice. Results: NGAL hly ex, ressed in gastric cancer tissues. The protein and mRNA expressions of NGAL rent $\quad-803$ cells treated with NGAL-siRNA were obviously reduced, and the amount Sells in G0/G1 phase was increased. Moreover, MGC-803 cells treated with NGAL-siRNA ted inhibited proliferation, enhanced apoptosis, decreased expressions of nuclear factor 4 a-light-chain-enhancer of activated B cells (NF-KB) as well as B-cell lymphoma-2 (Bcl$\rightarrow$ and increased expressions of cysteine-aspartic acid specific protease-9 (caspase-9) and $\mathrm{Bcl}$-associated $\mathrm{X}$ (Bax), as well as repressed tumorigenicity in vivo. Conclusion: NGAL gene silencing inhibits proliferation and promotes apoptosis of MGC-803 cells, which can provide a novel theory for treatment of gastric cancer. 


\section{Cellular Physiology \begin{tabular}{l|l|l} 
and Biochemistry & DOI.1159/000494236 & $\begin{array}{l}\text { C } 2018 \text { The Author(s). Published by S. Karger AG, Basel } \\
\text { www.karger.com/cpb }\end{array}$
\end{tabular} \\ Han et al.: NGAL Gene Silencing and Gastric Cancer}

\section{Introduction}

Gastric cancer is a common malignancy with a high mortality rate, accounting for nearly 70, 000 new cases and 650, 000 deaths every year [1,2]. It is the fourth most commr cancer diagnosed in men globally (the fifth in women), and the third leading cause of cance associated deaths in men (the fifth in women) [1]. The pathogenesis of gastric cancer lies in the accumulation of epigenetic and genetic alterations in tumor suppressor genes? oncogenes, which result in the dysregulation of many signaling pathways, thereby lea to the disturbance of cell cycle as well as the balance between cell proliferat and a [3]. Various factors, including helicobacter pylori infection, host genetic polyr epigenetic and environmental factors, and lifestyle, contribute to the occ pe tric cancer [4].

At present, gastric cancer is primarily treated with surgery, chemotherapy [5]. In spite of improvements in strategies for evi dete many patients are still diagnosed in advanced stage and don't receive ef curative surgery [2]. Furthermore, prognosis is still extremely poor for $\mathrm{m}$ natients gastric cancer, especially for those with tumor recurrence and metas It reported that poor overall survival in human gastric cancer was relate ty sive expression of epithelial-to-mesenchymal transition (EMT) biomarkers [ 7 as. ovidences indicate that neutrophil gelatinase-associated lipocali VGAL) expr on is remarkably reduced after induction of EMT by epidermal growth fac 10$]$. Ther $e$, novel therapy targeting NGAL might be a new treatment strategy.

NGAL, also known as Lipocalin-2 or Lcn-2 $\quad \mathrm{Kh}$ 5 $5 \mathrm{kDa}$ protein involved in the host defense against some gram-negative bacteriu rou inding with iron loaded bacterial siderophores, which limits the availabilit al nutrient to bacteria, leading to the inhibition of their growth and pathog $\mathrm{ct}$ 1]. It was frequently related to the size, stage, and invasiveness of tumor [12]. Recer as also indicated that abnormal expression of NGAL gene might happen $;$ conditions including tumor [12]. Therefore, we suspect that the NGAL ge contruate to the treatment of human gastric cancer. To achieve this, we studied silenced NGAL gene on the biological behavior of the MGC-803 cells to ovide a perimental basis for targeted NGAL gene therapy against human gastric

\section{cer.}

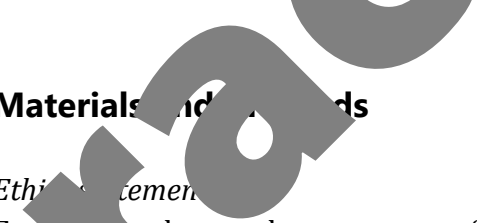

Ethi temer

xpu tal procedures were performed in line with the guidelines for using laboratory animals

oned an Provincial People' Hospital. This study was conducted in strict accordance with the

declara, on and approved by the Institutional Review Board of Henan Provincial People' Hospital r: 201712002). Participants provided written informed consent to participate in this study.

\section{Ctudy subjects}

This study included 87 patients with gastric cancer in Henan Provincial People' Hospital between ptember 2016 to October 2017. The patients who had a Karnofsky performance score (KPS) score of more than 70 and patients pathologically diagnosed with gastric cancer after operation were included [13]. Exclusion criteria concluded [14]: The patients with primary tumors in other parts, patients who had an infectious disease or an acute inflammatory response, patients who had a history of immune system disease or a chronic disease, and patients who recently used drugs, antibiotics, or chemotherapeutic drugs that affected white blood cells were excluded. All gastric cancer tissues and adjacent tissues were cut into small pieces, quickly stored in liquid nitrogen in a cryopreservation tube and then moved to a $-80^{\circ} \mathrm{C}$ refrigerator. 


\section{Cellular Physiology Cell Physiol Biochem 2018;50:694-705 \begin{tabular}{l|l|l} 
and Biochemistry & DOI: 10.1159/000494236 & $\begin{array}{l}\text { C } 2018 \text { The Author(s). Published by S. Karger AG, Basel } \\
\text { www.karger.com/cpb }\end{array}$
\end{tabular} \\ Han et al.: NGAL Gene Silencing and Gastric Cancer}

\section{Immunohistochemistry}

The positive expression rate of NGAL protein in gastric cancer tissues and adjacent normal tissues was detected by immunohistochemistry. Gastric cancer tissues and adjacent normal tissues were collected, fixed in $4 \%$ paraformaldehyde, embedded, and sliced into $4 \mu \mathrm{m}$ sections. After $60 \mathrm{~h}$ of baking, the sections were dewaxed with xylene, dehydrated with gradient alcohol, soaked in $3 \mathrm{H}_{2} \mathrm{O}_{2}$ for $10 \mathrm{~min}$ and wash by distilled water. High pressure antigen repair was performed for $90 \mathrm{~s}$, and the temperature was cooled $\mathrm{c}$ room temperature. Next, the sections were blocked with $5 \%$ bovine serum albumin (BSA) and incubated for $30 \mathrm{~min}$ at $37^{\circ} \mathrm{C}$. The diluted $100 \mu \mathrm{L}$ NGAL anti-rabbit primary antibody $\left(1: 1000\right.$, ab63929, Abcam ${ }^{\prime}$ Cambridge, MA, USA) was incubated at $4^{\circ} \mathrm{C}$ overnight. Next, diluted biotin-labeled goat anti-rabb 100; HY90046, Shanghai Hengyuan Biotechnology Co., Ltd., Shanghai, China) secondary a solution was added and incubated for $30 \mathrm{~min}$ at $37^{\circ} \mathrm{C}$. The sections were washed with phosp? saline (PBS), followed by addition of streptomycin anti-biotin peroxidase solution Biotechnology Co., Beijing, China) and incubation at $37^{\circ} \mathrm{C}$ for $30 \mathrm{~min}$. Positive dian. (Beijing Bioss Biotechnology Co. Ltd., Beijing, China) was used for coloration at $r$ sections were then soaked in hematoxylin for $5 \mathrm{~min}$, washed with tap water, immol acid for $4 \mathrm{~s}$ and rinsed in tap water for $20 \mathrm{~min}$ to return to blue. The average of NGAL posive staining was detected by ImageProplus inage analr finare (n GAL positive staining was detected by Image-Proplus image analy ftware ( $\mathrm{k}$. vbernetics, Silver Springs, MD, USA) under high magnification for quantitative analy was that normal positive cells were brown yellow [15]. Five fields isio high magnification $(x$ 400) were randomly selected in each section with 100 cells per field o percentage of positive cells in total cells. The experime ras independ repeated 3 times.

\section{Cell culture and treatment}

Human gastric cancer MGC-803 cell lines were Medical University. Cells were cultivated in RPMI 164 (FBS, HyClone, Logan, Utah, USA), $100 \mu \mathrm{g} / \mu$ thermostat (Thermo Scientific 8000, Thern They were passaged every $3 \sim 4 \mathrm{~d}$, and cell.

\section{Cell transfection}

Cell transfection was of manufacturer's protoce (siRNA) sequence is $5^{\prime}-$ 5'-AACGUACGCGGAAIIACUU, Company and all 803 cells were do (transfected ith N - si blank gre 6 tran ). Effects of RNA interference were detected $48 \mathrm{~h}$ after transfection.

\section{ideu search Institute of Oncology of Hunan} ture am containing $10 \%$ fetal bovine serum $00 \mu \mathrm{g} / \mu \mathrm{L}$ streptomycin) in a humidified

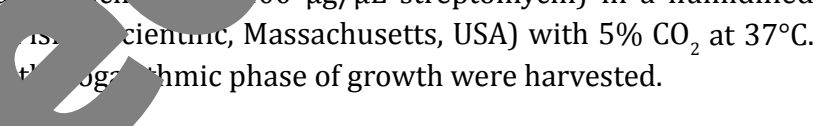

\section{verse vription-quantitative polymerase chain reaction (RT-qPCR)} nvitrog C., Carlsbad, CA, USA). NGAL-small interference RNA 'CCGG AGGACAATGA-3', and the negative control (NC) sequence is NGAL recombinant plasmids were purchased from Proptech vere synthesized by Shanghai GenePharma Co., Ltd., (Shanghai, China). MGCGAL-siRNA group (transfected with NGAL-siRNA sequence), NGAL group recombinant protein), control group (transfection of control sequence) and

er cells, vere washed by PBS three times, the total RNA of the cells was extracted using Trizol JNA was reverse-transcribed following the instructions of cDNA synthesis kit. The sequences GAL and GAPDH (internal reference) were amplified. The forward primer and reverse primer of GA were 5'-GAAGACAAAGACCCGCAAAAG-3' and: 5'-CTGGCAACCTGGAACAAAAG-3' respectively, and its fied product was $795 \mathrm{bp}$. The forward primer of GAPDH was 5'-ACCACAGTCCATGCCATCAC-3' and verse primer was 5'-TCCACCACCCTGTTGCTGTA-3', with its amplified product being $509 \mathrm{bp}$. The PCR amplification conditions were as follows: pre-denaturation at $94^{\circ} \mathrm{C}$ for $4 \mathrm{~min}$, and 30 cycles of denaturation at $95^{\circ} \mathrm{C}$ for $15 \mathrm{~s}$, renaturation at $55^{\circ} \mathrm{C}$ for $30 \mathrm{~s}$ as well as extension at $72^{\circ} \mathrm{C}$ for $45 \mathrm{~s}$. Next, $2 \%$ agarose gel electrophoresis was performed, with the pressure of stacking gel and separation gel at $80 \mathrm{~V}$ and $100 \mathrm{~V}$ respectively. Absorbance was detected using Gel Electrophoresis Image Analysis System (V1 Company, France). The ratio of absorbance of NGAL to that of GAPDH was regarded as the relative expression of NGAL mRNA. The above experiment was repeated 3 times. 


\section{Cellular Physiology Cell Physiol Biochem 2018;50:694-705 and Biochemistry \begin{tabular}{l|l} 
DOI: 10.1159/000494236 & $\begin{array}{l}\text { O } 2018 \text { The Author(s). Published by S. Karger AG, Basel } \\
\text { www.karger.com/cpb }\end{array}$ \\
\cline { 2 - 3 }
\end{tabular} \\ Han et al.: NGAL Gene Silencing and Gastric Cancer}

\section{Western blot analysis}

The protein of MGC-803 cells was extracted and determined as follows. The harvested cells were lysed, mixed with $3 \times$ loading buffer, stewed in boiling water for $10 \mathrm{~min}$, and then centrifuged at $10000 \mathrm{r} /$ $\min$ for $5 \mathrm{~min}(\mathrm{r}=400 \mathrm{~mm})$. The protein concentration was tested with ultraviolet spectrophotometric method. After $15 \%$ sodium dodecyl sulfate polyacrylamide gel electrophoresis (SDS-PAGE), the MGC-8 ${ }^{\circ}$ protein was transferred to nitrocellulose (NC) membrane using semi-dry electro-transfer method (12 $20 \mathrm{~min}$ ). Subsequently, the protein was pre-stained with ponceau $\mathrm{S}$ and its molecular weight was marked. After washing with Tris-buffered saline-Tween (TBST) buffer, the membrane was incubated with prim antibodies, including rabbit anti-human NGAL and Bcl2-associated X protein (Bax) polyclonal antib nude mice anti-human $\beta$-actin polyclonal antibody, cysteine-aspartic acid specific proteas (caspa. B-cell lymphoma-2 (Bcl-2) and nuclear factor kappa-light-chain-enhancer of activated B c caspase-3 and p53 (ClickSoftware Technologies Ltd, USA), at $4^{\circ} \mathrm{C}$ overnight. Thereafter caspase-3 and p53 (ClickSoftware Technologies Ltd, USA), at $4^{\circ} \mathrm{C}$ overnight. Thereafter
incubated with horseradish peroxidase-labeled secondary antibodies (goat anti-rabb anti-mouse IgG-HRP,; $1: 5000$; Abcam Inc., Cambridge, MA, USA) at $37^{\circ} \mathrm{C}$ for $2 \mathrm{~h}$, and va TBST (10 min each time) as well as once by TBS for $10 \mathrm{~min}$. Then, the membrane wa cvelop 1 LumiLight electrochemiluminescence (ECL) kit (Roche Holding Ltd., Basel, Switzerla. led, filmed and fixed with X-ray. After clean water washing, the expressions of apoptosis viated pro were determined. Image J software analysis was used for the grey value of the weste The i. of the grey value of the target gene to that of the reference gene was taken as the rela pro

\section{Flow cytometry}

Cells treated with $0.25 \%$ trypsin were centrifugea $(\mathrm{r}=17 \mathrm{~cm})$. The MGC-803 cells were washed by PBS, afte. supernatant was discarded and cells were collected simutaneously. They were washed two tim ath $\quad 1$ PBS, and fixed in $80 \%$ ethanol at $4{ }^{\circ} \mathrm{C}$ overnight. After washing three times with PBS, cells re ended in $0.1 \mathrm{mg} / \mathrm{ml}$ propidium iodide for staining at room temperature for a half ho ith cycle was detected by flow cytometry (Beckman Coulter Inc., Fullerton, California aty. above experiment was repeated 3 times.

Water soluble tetrazolium-1

Cells in the NGAL-siRNA, con

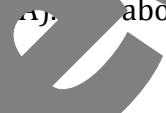
$10^{4}$ cells $/ \mathrm{mL}$. A total of $200 \mu \mathrm{L}$ the $\mathrm{c}$ eded in a 96-well plate. After 24,48 and $72 \mathrm{~h}$ of incubation, $20 \mu \mathrm{L}$ of WST-1 reagent (Fy a Maixin ch., Co., Ltd., Fuzhou, China) was put into the plate as well as incubated for $4 \mathrm{~h}$. OD at $\mathrm{nm}\left(C \mathrm{D}_{150}\right)$ of each well was measured by microplate reader in triplicate. Inhibition rate of prolifaratic $-\mathrm{OD}_{450}$ value in the NGAL-siRNA group $/ \mathrm{OD}_{450}$ value in the control group) $\times 100 \%$.

Flow cy netry $O$

Afte sfecti 8 and $72 \mathrm{~h}$, non-transfected cells in the NGAL-siRNA, NGAL, control and blank $g^{\wedge}$ 'vups $\mathrm{w}$ llected, mixed with $60 \mathrm{~mL}$ of deionized water and $20 \mathrm{~mL}$ of binding buffer and washed SS. A. $5 \sim 12.5 \times 10^{4}$ cells were suspended with $250 \mu \mathrm{L}$ of binding buffer to reach a final cell ation o,$\sim 5 \times 10^{4}$ cells $/ \mathrm{mL}$. Subsequently, $195 \mu \mathrm{L}$ of cell suspension together with $5 \mu \mathrm{L}$ of Annexin V/flu sothiocyanate (FITC; $20 \mu \mathrm{g} / \mathrm{ml}$ ) (Dako North American Inc., CA, USA) was incubated at room perature for $10 \mathrm{~min}$ without light. Thereafter, $190 \mu \mathrm{L}$ of mixed solution was used to rinse and re-suspend sl $1 \mathrm{~s}$, and the cells were stained by $10 \mu \mathrm{l}$ of $20 \mu \mathrm{g} / \mathrm{mL}$ propidium iodide (PI). Apoptosis of cells was ced with flow cytometry.

\section{Xenograft in nude mice}

Forty-five BALB/c nude mice weighing 18-20 g and aged 6-7 weeks were purchased from Shanghai SLAC Laboratory Animal Co., Ltd., (Shanghai, China). Mice were housed under specific-pathogen-free conditions in Experimental Animal Center of Chongqing Medical University. Mice were randomly divided into the following 3 groups $(n=15)$ : NGAL-siRNA group, control group and blank group. Mice in the NGALsiRNA group were hypodermically injected with same volume of MGC-803 cells stably expressing NGALsiRNA; mice in the control group were hypodermically injected with the MGC-803 cells stably expressing random control sequence; and mice in the blank group were subcutaneously injected with MGC-803 cells. 


\section{Cellular Physiology Cell Physiol Biochem 2018;50:694-705

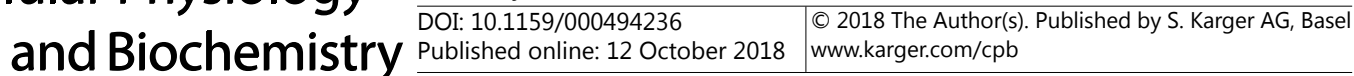 \\ Han et al.: NGAL Gene Silencing and Gastric Cancer}

The major diameter (a) and minor diameter (b) of tumors in mice were measured, and the tumor volume (TV) was calculated by TV $=1 / 2 \times a \times b^{2}$. Growth conditions of tumors in nude mice were observed and growth curve was plotted. Nude mice were sacrificed on the $30^{\text {th }}$ day. Their tumor tissues were weighed, fixed in neutral formalin, dehydrated, embedded in paraffin and sectioned. The levels of proliferative cell nuclear antigen (PCNA) in each group were determined using immunohistochemical staining. The sectio were added with serum blocking buffer, washed three times by PBS ( 5 min each time), incubated in $3 \% \mathrm{H}_{2} \mathrm{O}$ for $10 \mathrm{~min}$ as well as washed three times by PBS ( 5 min each time). Then the sections were incubated with PCNA primary antibody (1: 1000; ClickSoftware Technologies Ltd, USA) at $4^{\circ} \mathrm{C}$ overnight, rewarmed at $\mathrm{r}$ temperature for $45 \mathrm{~min}$ the next day, and washed three times by PBS ( 5 min each time), followed by a secondary antibody (1: 5000; ClickSoftware Technologies Ltd, USA), incubation at room peratu. $20 \mathrm{~min}$ and three PBS washes (5 min each time). The experiment results were evaluated $u$ blind method. Five high power fields of vision $(\times 400)$ were randomly selected in ev cells were counted in each field. DAB staining was yellowish-brown and positive 3-Am. (AEC) staining was red. The percentage of positive cells to total tumor cells was calcha

\section{Statistical analysis}

All data were analyzed by SPSS 21.0 software (IBM Corporati data were expressed as mean \pm standard deviation. Differences b roups examined with $t$-test. Analysis of variance (ANOVA) and analysis of covariance (A VA t for multiple group comparisons. $p<0.05$ was considered to represent significant differe

\section{Results}

NGAL is highly expressed in gastric cancer

Initially, we observed positive prot and adjacent normal tissues. The rest f NGAL in the gastric cancer tissues and adjacent normal tissues. The resy th Snowed that positive cells of NGAL protein expression were stained brown yello expression of NGAL in the ge an significantly higher than those in the adjacent normal tissues $(p<0 \quad$ These ruvats demonstrated that NGAL is highly expressed in gastric cancer tissues.

NGAL gene silencing

We performed RT-q. expressions of $y$ siRNA group s? 0.05). The pres in ibits he mRNA and protein expressions of NGAL in MGC-803 cells vestern blot analysis to determine the mRNA and protein transfection groups. The expression of NGAL in the NGALntly lower than that in the blank and control groups (both $p<$ ntly lower than that in the blank and control groups (both $p<$
GAL in the NGAL group was significantly higher than that in the

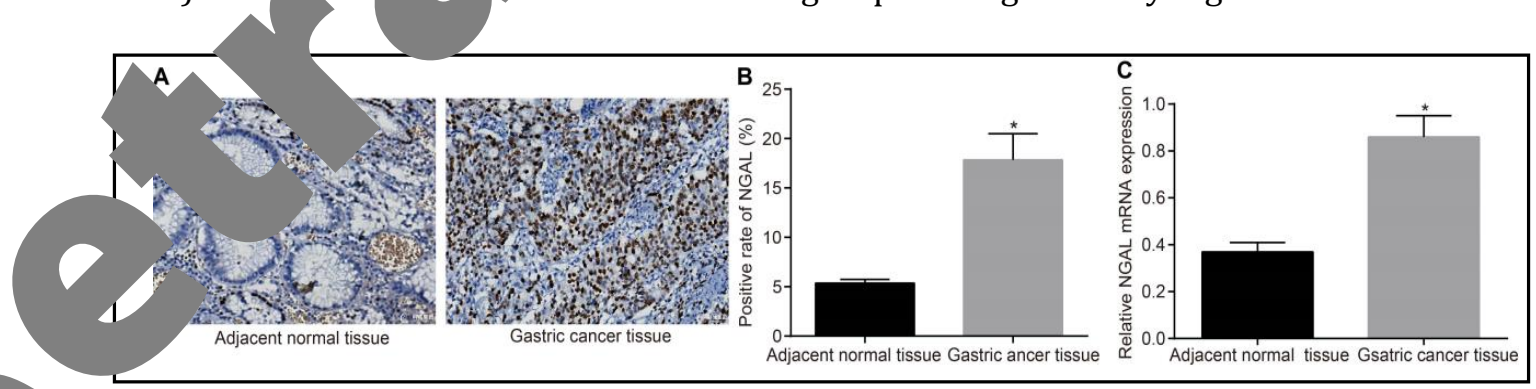

Fig. 1. Immunohistochemistry and RT-qPCR reveal that NGAL is highly expressed in gastric cancer tissues. Note: Panel A-B, immunohistochemistry $(\times 400)$ shows that positive protein expression of NGAL in the gastric cancer tissues is significantly higher than that in the adjacent normal tissues; Panel C, RT-qPCR shows that mRNA expression of NGAL in the gastric cancer tissues is significantly higher than that in the adjacent normal tissues; *, p<0.05 vs. the adjacent normal tissues; NGAL, neutrophil gelatinase-associated lipocalin; siRNA, small interfering RNA; RT-qPCR, reverse transcription-quantitative polymerase chain reaction. The data are presented as mean \pm standard deviation, analyzed by t test. The experiment was independently repeated three times. 

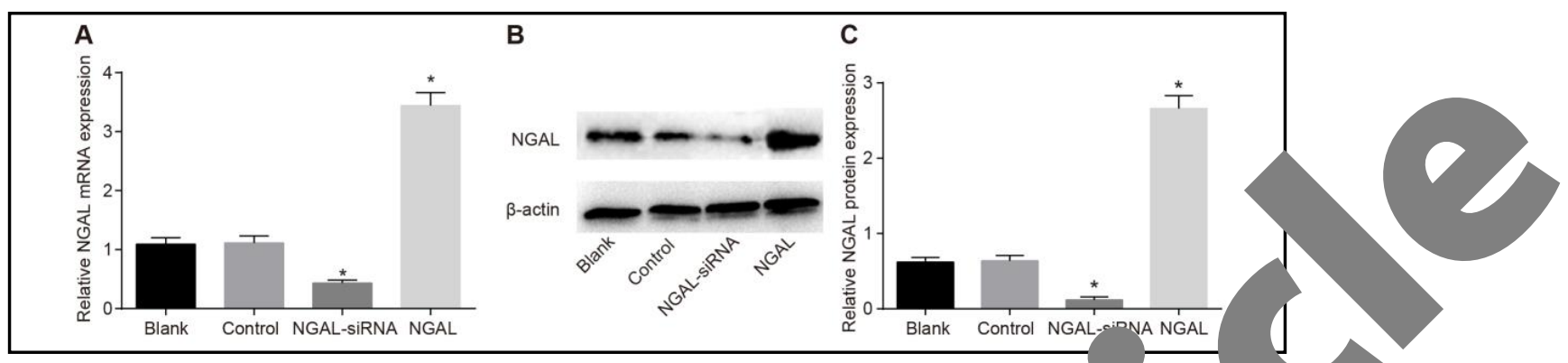

Fig. 2. RT-qPCR and western blot analysis demonstrate that NGAL gene silencing inhibits ne RNA protein expressions of NGAL in MGC-803 cells. Note: Panel A, the histogram shows that 'GAI ge. inhibits the mRNA expression of NGAL in MGC-803 cells, determined by RT-qPCR; Pa analysis shows that NGAL gene silencing inhibits the protein expression of NGAL in MG vs. the control and blank groups; NGAL, neutrophil gelatinase-associated lipocalin; RNA; RT-qPCR, reverse transcription-quantitative polymerase chain reaction. mean \pm standard deviation, analyzed by one-way ANOVA. The expmiment was endently repeated three times.

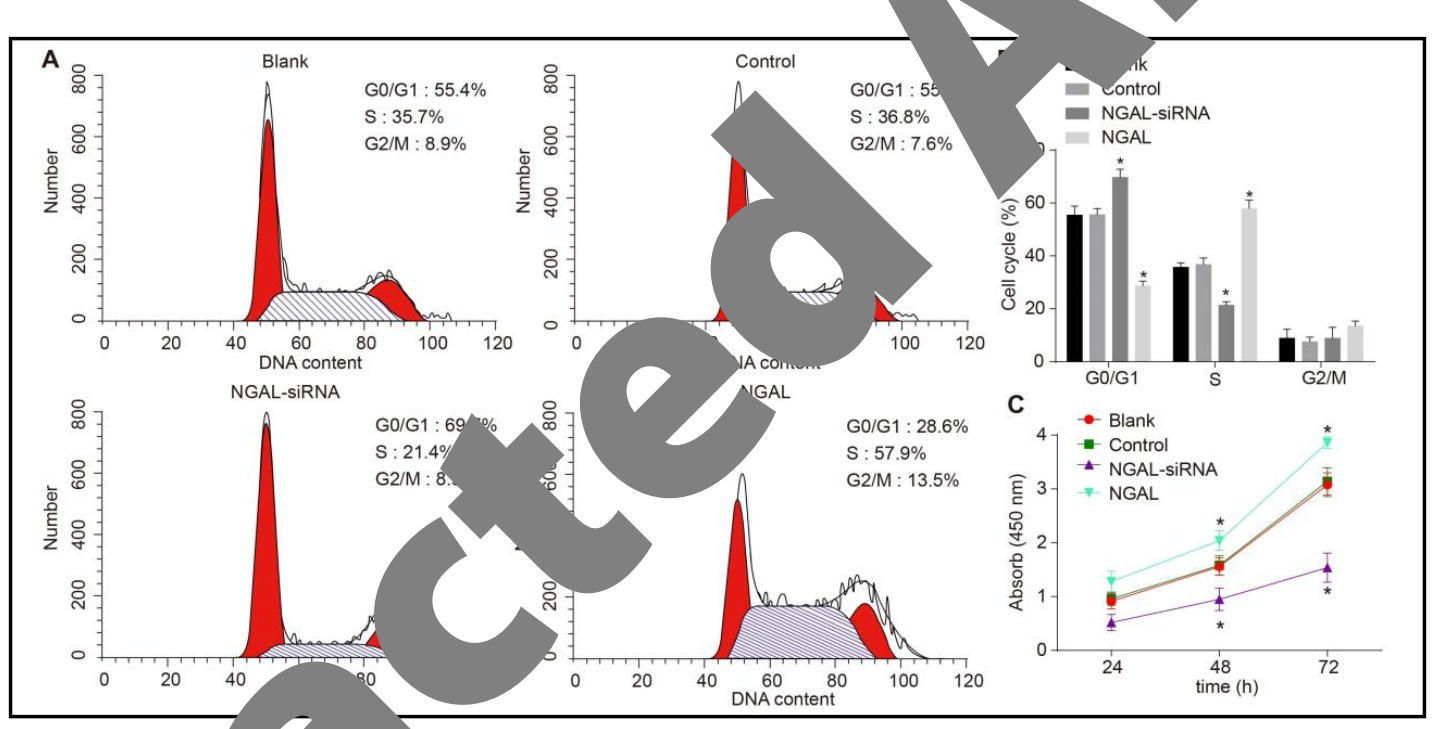

Fig. 3. Flow cyt re proliferation MG ns. Notes: Panel A-B, flow cytometry illustrates that the amount of MGC-803 cells at $f$ hase lously increased by NGAL-siRNA but that at $S$ phase is decreased; Panel C, WST1 sc ilh that NGAL gene silencing inhibits the proliferation of MGC-803 cells; *, p<0.05 vs. the and b roups; NGAL, neutrophil gelatinase-associated lipocalin; siRNA, small interfering RNA. ar $\sim$ presented as mean \pm standard deviation, analyzed by one-way ANOVA. The experiment was depo repeated three times.

and control groups (both $p<0.05$ ) (Fig. 2). These results suggested that NGAL gene $d$ have a comparatively high interfering efficiency.

NGAL gene silencing inhibits the progression of cell cycle and proliferation of MGC-803 cells

Flow cytometry was used for analysis of cell cycle, which exhibited that the amount of cells at $\mathrm{G}_{0} / \mathrm{G}_{1}$ phase was obviously increased in the NGAL-siRNA group compared to the control and blank groups, while the number of cells at $S$ phase was obviously decreased (all $p<0.05$ ). The amount of cells at $\mathrm{G}_{0} / \mathrm{G}_{1}$ phase was obviously decreased in the NGAL group compared to the control and blank groups, while the number of cells at $\mathrm{S}$ phase was obviously increased (all $p<0.05$ ) (Fig. 3A-B). The data indicated that NGAL gene silencing 
can arrest MGC-803 cells at $G_{0} / G_{1}$ phase in the progression of cell cycle. We further observed the relationship between NGAL gene silencing and cell proliferation of MGC-803 cells. The results showed that NGAL-siRNA could notably inhibit the proliferation of MGC-803 cells while NGAL could induce this proliferation in a time-independent manner (Fig. 3C). The number of cells at $G_{2} / M$ phase showed no significant difference among the three groups $(-$ $p>0.05$ ). The cell cycle and proliferation of MGC-803 cells were not significantly differen between the blank and control group (all $p>0.05$ ). Taken together, NGAL gene silencing could inhibit the progression of cell cycle and proliferation of MGC-803 cells.

\section{NGAL gene silencing promotes apoptosis of MGC-803 cells}

We conducted additional flow cytometry to investigate the effect of NGAL o cell apoptosis. The results displayed that the apoptosis rate of MGC-803 siRNA group was obviously higher in comparison to the control and blat $<0.05$ ), while the apoptosis rate of MGC-803 cells in the NGAL group ys lower (both $p<0.05$ ). There were no significant differences in the apoptosis r of M 3 cells between the control and blank groups ( $p>0.05$ ) (Fig. 4). The results d that NGAL gene silencing could promote the apoptosis of human gastric ca MGC-80

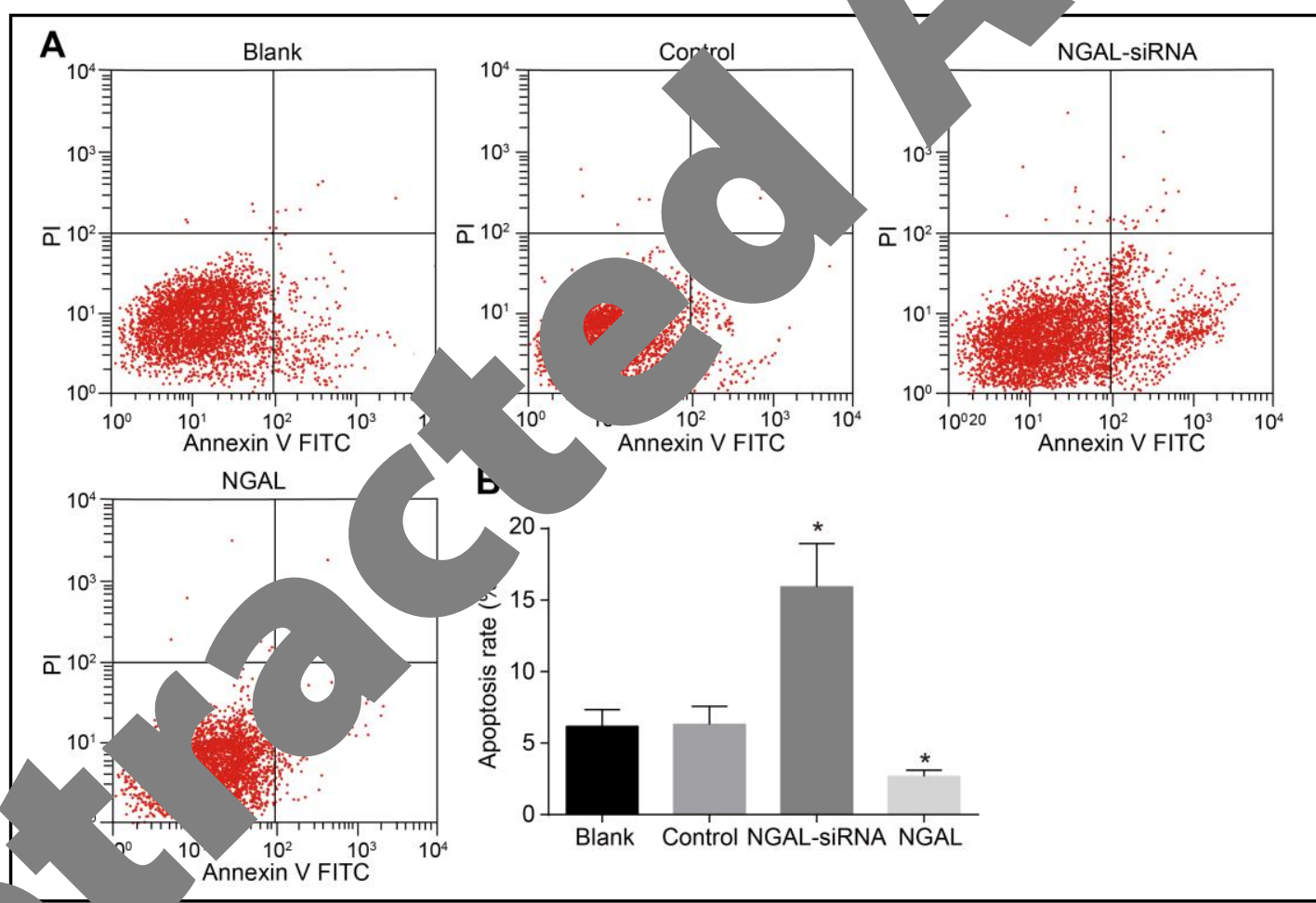

4. Flow cytometry demonstrates that NGAL gene silencing promotes apoptosis of MGC-803 cells. Notes: ar $\lambda$, apoptosis detection images reveal that NGAL gene silencing promotes apoptosis of MGC-803 cells;

$\mathrm{B}$, histogram of MGC-803 cell apoptosis displays that NGAL gene silencing promotes apoptosis of IVGC-803 cells; *, p<0.05 vs. the control and blank groups; NGAL, neutrophil gelatinase-associated lipocalin; siRNA, small interfering RNA. The data are presented as mean \pm standard deviation, analyzed by one-way ANOVA. The experiment was independently repeated three times. 


\section{Cellular Physiology \begin{tabular}{l|l|l} 
and BOI: 10.1159/000494236 & $\begin{array}{l}\text { () 2018 The Author(s). Published by S. Karger AG, Basel } \\
\text { www.karger.com/cpb }\end{array}$
\end{tabular} \\ Han et al.: NGAL Gene Silencing and Gastric Cancer}

$N G A L$ gene silencing decreases expressions of apoptosis-inhibiting proteins $N F-\kappa B$ and $B c l-$ 2 and increases expressions of pro-apoptotic proteins caspase-9, Bax, caspase-3 and p53 in MGC-803 cells

Western blot assay was used to explore whether NGAL could influence the prote expressions of apoptosis-related proteins. The results showed that the protein expression of NF- $\kappa B$ and Bcl-2 in MGC-803 cells in the NGAL-siRNA group were significantly reduced compared with the control and blank groups, while the protein expressions of caspas Bax, caspase-3 and p53 were significantly increased (all $p<0.05$ ). In comprison to control and blank groups, the protein expressions of NF- $\kappa \mathrm{B}$ and Bcl-2 in MGC-8 NGAL-siRNA group were significantly increased, while the protein expressions of Bax, caspase-3 and p53 were significantly decreased (all $p<0.05$ ). Howeve th exp ons of NF- $\kappa$ B, Bcl-2, caspase- 9 and Bax in the control and blank groups $h$ sign $t$ differences (all $p>0.05$ ) (Fig. 5). Therefore, it was concluded that NGAL could decrease expressions of apoptosis-inhibiting proteins and increase oress i proapoptotic proteins.

NGAL gene silencing suppresses tumor growth in nudt

By comparing the tumor growth curve and tumor tissi NGAL-siRNA, control and blank groups at $30 \mathrm{~d}$ after tumor the tumor growth rate in the NGAL-siRNA gro vas signific control groups $(p<0.05)$. The weight of tumor $t_{1}$ in the bla sroup, NGAL-siRNA group and control group was (1.65 $\pm 0.18) \mathrm{g},(0.82 \pm 0.11) \mathrm{g}$ and $(1.68 \pm 0.21) \mathrm{g}$, respectively, suggesting that the tumor in blank and control groups was significantly larger than that in the NGAL-siRNA grou (both $p<0.05$ ). Furthermore the comparison of $P f$ level among the three $g$ exhibits that the com with the blank and co groups, the group showe th decreased CNA ve woth $p<0.0$ g. 7). results f rtbor fied that NGAL silen could inhibit liferat $n$ of the human er MGC-803 cells ivo, mereby reducing the
rigenesis in nude mice.

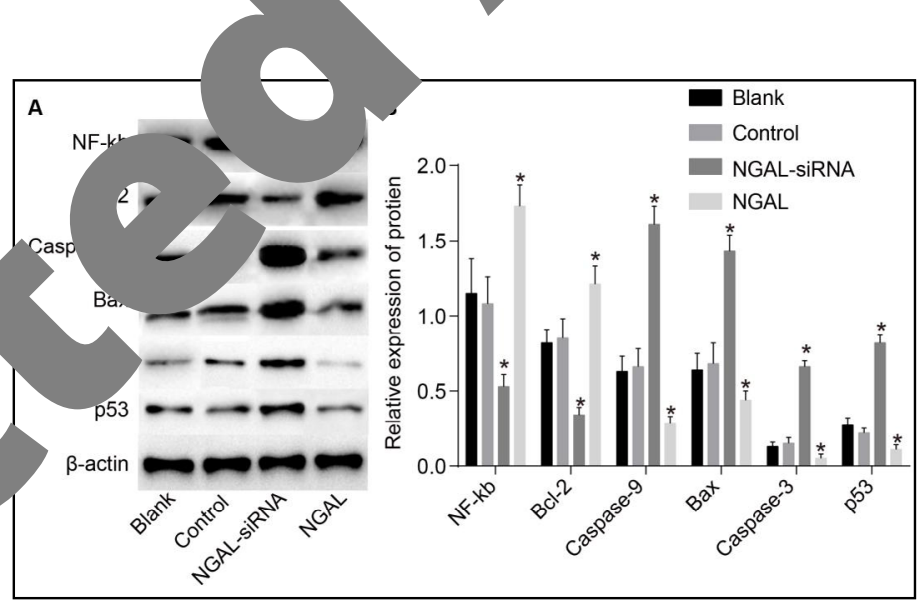

Fig. 5. Western blot assay shows that NGAL gene silencing decreases expressions of apoptosis-inhibiting proteins NF- $\kappa \mathrm{B}$ and Bcl-2 and increases expressions of pro-apoptotic proteins caspase-9, Bax, caspase- 3 and p53 in MGC-803 cells. Notes: Panel A, protein bands of the apoptosis-related proteins show that NGAL gene silencing decreases expressions of apoptosis-inhibiting proteins NF- $\kappa B$ and $\mathrm{Bcl}-2$ and increases expressions of pro-apoptotic proteins caspase-9, Bax, caspase-3 and p53 in MGC-803 cells; Panel B, statistical chart shows that NGAL gene silencing decreases expressions of apoptosisinhibiting proteins NF- $\kappa \mathrm{B}$ and $\mathrm{Bcl}-2$ and increases expressions of proapoptotic proteins caspase-9, Bax, caspase-3 and p53 in MGC-803 cells; *, p<0.05 vs. the control and blank groups; NGAL, neutrophil gelatinase-associated lipocalin; siRNA, small interfering RNA; Bcl2, B-cell lymphoma-2; Bax, Bcl2-associated X protein; caspase-9, cysteine-aspartic acid specific protease-9. The data are presented as mean \pm standard deviation, analyzed by one-way ANOVA. The experiment was independently repeated three times. 

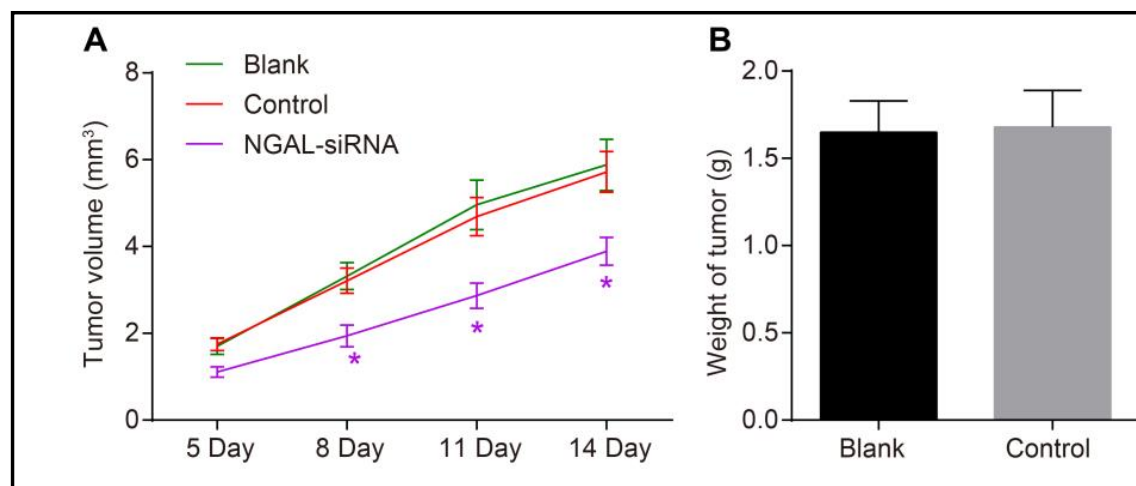

Fig. 6. NGAL gene silencing suppresses tumor growth rate and tumor tissue weight after tumorigenesis. Notes: Panel A, tumor growth curve shows that tumor growth group is significantly lower than the blank and control groups; Panel B, tumor t; weigh de mice among the NGAL-siRNA, control and blank groups was measured at $30 \mathrm{~d}$ after tu. enesis, showing that the tumor in blank and control groups was significantly larger than $t^{\prime}$ the NGAL $\quad$ group; ${ }^{*}, \mathrm{p}<0.05$ vs. the control and blank groups; NGAL, neutrophil gelatinase-asso in small interfering RNA. The data are presented as mean \pm standard deviation, analyze on $\quad$ OVA. The experiment was independently repeated three times.

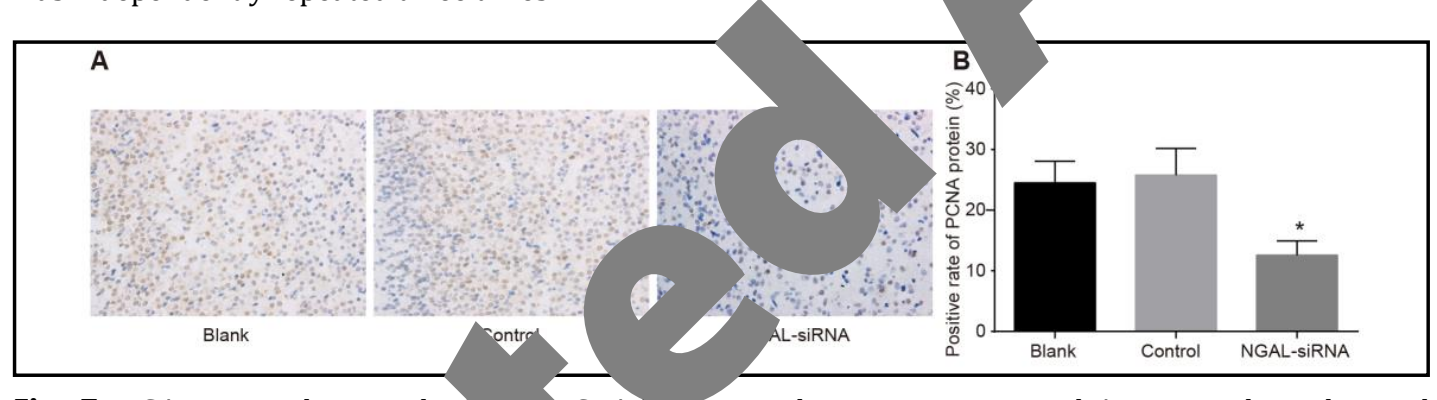

Fig. 7. NGAL gene silencing dec PCNA level in nude mice. Notes: Panel A, immunohistochemical staining $(\times 400)$ shows that th GAL- Jup have significantly decreased PCNA level in comparison to the control and blank gro Panel B, hucogram suggests that the NGAL-siRNA group have significantly decreased PCNA level in co ison the control and blank groups; *, p<0.05 vs. the control and blank groups; NGAL, neutr loel. sociated lipocalin; siRNA, small interfering RNA; PCNA, proliferating cell nuclear antigr are presented as mean \pm standard deviation, analyzed by one-way ANOVA. The experiment was de ra epeated three times.

\section{Dic on}

ultin therapy combined with surgery, radiation therapy and systemic herap, has constantly improved the treatment of advanced gastric cancer [16]. How prognosis is still poor. Therefore, it is urgent to develop novel targeted therapy. $\mathrm{AL}$, a protein belonging to lipocalin family, is expressed by activated neutrophils and
ar is epithelial cells. It functions to protect against apoptosis, oxidative stress, and bacterial -tion, and may play a critical role in the treatment of tumor [17]. Overexpression of NGAL ihanced the migration as well as invasion of the tumor cells in vivo and in vitro. On the contrary, neutralization and knockdown of it reduced the migration and invasion of tumor cells [18]. Therefore, the aim of our study is to explore the effect of NGAL gene silencing on human gastric cancer MGC-803 cells, with the hope of offering a new therapeutic method in the treatment of gastric cancer. The results showed that NGAL gene silencing contributes to controlling gastric cancer progression through inhibiting cell proliferation and enhancing cell apoptosis in MGC-803 cells.

In this study, RNA interference (RNAi) technology, which has a strong effect on posttranscriptional gene silencing and has been widely used to target oncogenes and inhibit

\section{KARGER}




\section{Cellular Physiology \begin{tabular}{ll|l} 
and Biochemistry Published online: 12 October 2018 & $\begin{array}{l}\text { @ } 2018 \text { The Author(s). Published by S. Karger AG, Basel } \\
\text { www.karger.com/cpb }\end{array}$ \\
\hline
\end{tabular}

cancer growth, was used to silence NGAL gene [19]. We firstly constructed siRNA sequences targeting the NGAL gene and stable transfectants were selected for investigation, which were indeed effective. Then we assessed the expression of NGAL gene in MGC-803 cells. We found that the expressions of NGAL mRNA and protein were highly suppressed in the NGAL-siRNA group in comparison to the blank and control groups, suggesting that NGAL participat in the development and evolvement of gastric cancer. Similarly, Michalak et al. supporte that NGAL has been considered to be an oncogene in gastric cancer, and high expression of NGAL was also observed in gastric cancer. It seemed that the intensity of its over-express was linked to neoplasm [20]. Additionally, it has been found that urine NGAL is cignific increased and related to the degree of albuminuria in type 2 diabetic nephro ny $_{\text {( }}$ : 2 [21]. Besides, contrast-induced acute kidney injury (CIAKI) presented with el plasma biomarker of NGAL $24 \mathrm{~h}$ after iopromide injection [22]. Furthermo macrophages that overexpressing NGAL was related to decreased kidney it and inflammation [23].

Most importantly, compared with the control and blank grours e fou at the amount of cells arrested at $G_{0} / G_{1}$ phase in the NGAL-siRNA group was cicantly increased, while the number of cells at S-phase was significantly rer The r demonstrated that silencing of NGAL led to a reduction in the prolifer the inhibitory function of silenced NGAL on the developi to 03 cells was timedependent. After $72 \mathrm{~h}$, the apoptosis rate in the NGAL-siRN than that in the blank and control groups. $\mathrm{L}$, one of ipocalin family members characterized by the ability to bind and transp all lipoph substances, was found to be overexpressed in many kinds of tumors [24] mposed of 178 amino acids and was found to form a complex with the gelatinase veli trix metalloproteinase-9, and its overexpression was related to poor prognosi oge that it might be a biomarker for the prognosis of patients [25]. Previoy shown that the down-regulation or deficiency of NGAL inhibited cell grov th 7].

After $72 \mathrm{~h}$, the expressions of $\mathrm{NF}$ a 2 proteins in the NGAL-siRNA group were significantly lower than the he control groups, while the expressions of caspase-9 caspase-3, p53 an proten were significantly higher. NF- $\kappa B$, an important transcription element, co rols cellular processes under pathologic or normal conditions, including tis woun aling, inflammation, cell proliferation, angiogenesis and cell differentiation $\quad \mathrm{NF}^{-\mathrm{R}} \mathrm{w}$ will stimulate cell proliferation in response to cell injury [29]. Bcl-2 is a kev nlaye cic program of eukaryotic cells favoring survival through inhibiting cell hose overexpression has been found in many kinds of cancers, such as carcin nia or lymphomas [30]. Caspase-9, a protein mainly localized in mitochond is cit a regulatory player in mitochondria-mediated apoptosis pathway. Activate pase aves and activates caspase-7 and -3 directly, leading to the biochemical $d$ strucu f the cells [31]. Bax is one of the pro-apoptotic genes, the overexpression of resu. apoptosis in a number of cells [32]. Bax expression seems to play a critical uppresing the development of cancer, and the decrease in Bax expression has been of cancers [33]. The apoptosis-related proteins, such as caspase 3 and p53 could ract with NGAL $[34,35]$.

\section{Conclusion}

In conclusion, our results demonstrated that NGAL silencing contributes to inhibiting the proliferation of MGC-803 cells and promoting cell apoptosis. However, this study also has some drawbacks including small size of specimens. Consequently, we really look forward to having more projects to further verify our conclusion. In addition, we will further study the mechanisms regarding NGAL and apoptosis-related proteins using protein interaction method.

\section{KARGER}




\section{Cellular Physiology Cell Physiol Biochem 2018;50:694-705 \begin{tabular}{l|l|l} 
and Biochemistry & DO.1159/000494236 & $\begin{array}{l}\text { C } 2018 \text { The Author(s). Published by S. Karger AG, Basel } \\
\text { www.karger.com/cpb }\end{array}$
\end{tabular}}

Han et al.: NGAL Gene Silencing and Gastric Cancer

\section{Acknowledgements}

Thisstudy was supported by "Relationshipbetween methylenetetrahydrofolatereductase gene polymorphism and sensitivity of colorectal cancer to fluorouracil chemotherapy drug (No. 201403190). We thank the reviewers for critical comments.

\section{Disclosure Statement}

No conflict of interests exists.

\section{References}

1 Ohtsu A, Shah MA, Van Cutsem E, Rha SY, Sawaki A, Park SR, Lim HY, Yamada Y, M, Kang YK: Bevacizumab in combination with chemotherapy as fi therapy cancer: a randomized, double-blind, placebo-controlled phase II Tahara T, Okubo M, Shibata T, Kawamura T, Sumi K, Ishizuka T, Nag $\mathrm{N}$, Hirata I: Association between common genetic variants in pre-mi gastric cancer treated with chemotherapy. Anticane s 2014;34:51

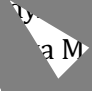
ncol 2u, 29:3968-3976. Berger H, Marques MS, Zietlow R, Meyer TF, Machado Helicobacter 2016;21 Suppl 1:34-38.

4 Conteduca V, Sansonno D, Lauletta G, Russi S, Ingra cancer: state of the art (review). Int J Oncol 2013;4

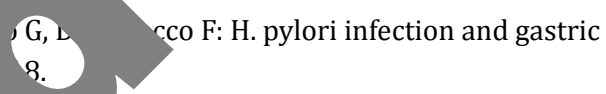
Jing X, Cheng W, Wang S, Li P, He L: Resver cells via the PTEN-regulated PI3K/Akt si Duan JT, Wang XM, Zhang SQ, Zhao GJ: E gastric MGC-803 cells. Int $\mathrm{J} \mathrm{Cl}$

$7 \quad$ Song F, Yang D, Liu B, Guo Y, Z $\mathrm{X}$, Chen K: Integrated micr YA no characterized by the mir ${ }^{\prime} \quad$ family. $\_$ancer Res 2014;20:878-889.

TS, Wu RC, Pang IS, Cheng CT, Wang SY, Juang HH, Yeh CN: Lipocalin 2 (LCN2) is a promising

rget fo ngiocarcinoma treatment and bile LCN2 level is a potential cholangiocarcinoma diagnostic ker Sci vep 2016;6:36138.

-Weiler R, Schroll A, Engl S, Nairz M, Talasz H, Seifert M, Weiss G: Neutrophil gelatinase-associated lipocalin and interleukin-10 regulate intramacrophage Chlamydia pneumoniae replication by modulating tracellular iron homeostasis. Immunobiology 2013;218:969-978. Lippi G, Meschi T, Nouvenne A, Mattiuzzi C, Borghi L: Neutrophil gelatinase-associated lipocalin in cancer. Adv Clin Chem 2014;64:179-219.

Spratt DE, Dess RT, Zumsteg ZS, Lin DW, Tran PT, Morgan TM, Antonarakis ES, Nguyen PL, Ryan CJ, Sandler HM, Cooperberg MR, Posadas E, Feng FY: A Systematic Review and Framework for the Use of Hormone Therapy with Salvage Radiation Therapy for Recurrent Prostate Cancer. Eur Urol 2018;73:156-165.

14 Zhang LJ, Wu B, Zha ZL, Zhao H, Yang W, Chen XH, Jiang B, Jiang YF, Yin JL: [The comparation of fusion targeting biopsy and systematic biopsy in the clinical diagnosis of prostate cancer: a meta-analysis]. Zhonghua Yi Xue Za Zhi 2017;97:1694-1698. 


\section{Cellular Physiology Cell Physiol Biochem 2018;50:694-705 \begin{tabular}{ll|l} 
DOI: 10.1159/000494236 & $\begin{array}{l}\text { O } 2018 \text { The Author(s). Published by S. Karger AG, Basel } \\
\text { www.karger.com/cpb }\end{array}$ \\
\hline
\end{tabular}}

Han et al.: NGAL Gene Silencing and Gastric Cancer

15 Kelkar MG, Thakur B, Derle A, Chatterjee S, Ray P, De A: Tumor suppressor protein p53 exerts negative transcriptional regulation on human sodium iodide symporter gene expression in breast cancer. Breast Cancer Res Treat 2017;164:603-615.

16 Yamaguchi H, Kitayama J, Ishigami H, Emoto S, Yamashita H, Watanabe T: A phase 2 trial of intravenous and intraperitoneal paclitaxel combined with S-1 for treatment of gastric cancer with macroscopic peritoneal metastasis. Cancer 2013;119:3354-3358.

17 Daniels LB, Barrett-Connor E, Clopton P, Laughlin GA, Ix JH, Maisel AS: Plasma neutrophil gelatinaseassociated lipocalin is independently associated with cardiovascular disease and mortality in communi dwelling older adults: The Rancho Bernardo Study. J Am Coll Cardiol 2012;59:1101-1109.

18 Chung IH, Wu TI, Liao CJ, Hu JY, Lin YH, Tai PJ, Lai CH, Lin KH: Overexpression of lipocalin 2 cervical cancer enhances tumor invasion. Oncotarget 2016;7:11113-11126.

19 Geng ZM, Zhang M, Pan XT, Wang L: Bcl-2 gene silencing by RNA interference inhibits human gallbladder carcinoma cell line GBC-SD in vitro and in vivo. Oncol Rep 2013;30

20 Michalak L, Bulska M, Kudlacz K, Szczesniak P: Role of oncogene 24p3 neutrophil ge lipocalin (NGAL) in digestive system cancers. Postepy Hig Med Dosw (Online) 201(

21 Wu J, Shao X, Lu K, Zhou J, Ren M, Xie X, Liu J, Xu Y, Ding Y, Shen X, Zhu C: Urina.

22 Tan X, Zheng X, Huang Z, Lin J, Xie C, Lin Y: Involvement of S100A Pathway in Contrast-Induced Acute Kidney Injury. Cell Physiol Bio

-23 Guiteras R, Sola A, Flaquer M, Hotter G, Torras J, Grinyo JM, Cruzado Ameliorated Kidney Fibrosis in the UUO Mice Mode 'l Physiol Bioc. ciol Bioch $7 ; 42: 594-602$. 1026 0.

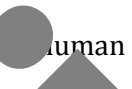
Zhang PX, Chang JX, Xie JJ, Yuan HM, Du ZP, Zhang FK, Xu LY, Li EM: dlation of neutrophil gelatinase-associated lipocalin expression by C/EBPb+ g carcinoma cells. Oncol Lett 2012;4:919924.

25 Wang HJ, He XJ, Ma YY, Jiang XT, Xia YJ, Ye ZY, Zhao associated lipocalin in gastric cancer: a pote-1 bio Anat Rec (Hoboken) 2010;293:1855-186

26 Song B, Zhang H, Jiang L, Chi Y, Tian J, D growth of human lung adenor Biochim Biophys Sin (Shangha
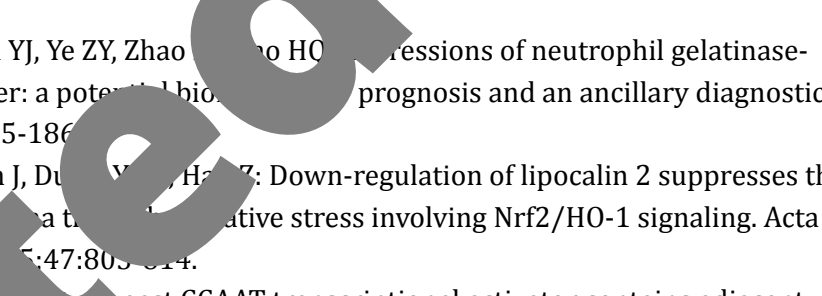
prognosis and an ancillary diagnostic test.

$\checkmark 27$ Olesen JT, Guarente L: The PLS reast CCAAT transcriptional activator contains adjacent domains for subunit ass con and L cognition: model for the HAP2/3/4 complex. Genes Dev 1990;4:1714-1729.

-28 Nair VS, Gevaert O Davic. F-FDG PET ty tumor met?

-29 Mursh Farl L Wson MI, Fontana JA: NF-kappaB p65 recruited SHP regulates PDCD5-mediated apo in can s. Apoptosis 2014;19:506-517. itis SK, West R: NF-kappaB protein expression associates with (18)
in ncer 2014;83:189-196

Wer Q, Sun X, Li D, Song H, Li X, Song J, Hua K, Fang L: MicroRNA-497 induces cell apoptosis by gativ ylating Bcl-2 protein expression at the posttranscriptional level in human breast cancer. Int J Exp Pà ol 2015;8:7729-7739.

$\mathrm{C}$, Cheng J, Li Z, Liu C: HAX-1 inhibits apoptosis in prostate cancer through the suppression of

8 casspase-9 activation. Oncol Rep 2015;34:2776-2781. a-induced apoptosis in anaplastic thyroid cancer cells. J Clin Endocrinol Metab 2005;90:3583-3591. Nunes CT, Miners KL, Dolton G, Pepper C, Fegan C, Mason MD, Man S: A novel tumor antigen derived from enhanced degradation of bax protein in human cancers. Cancer Res 2011;71:5435-5444.

Chakraborty S, Kaur S, Guha S, Batra SK: The multifaceted roles of neutrophil gelatinase associated lipocalin (NGAL) in inflammation and cancer. Biochim Biophys Acta 2012;1826:129-169.

35 Chappell WH: p53 and NGAL: dual regulatory roles in advanced prostate cancer [Doctoral Dissertation]. Greenville, NC: East Carolina University 2011. 